\title{
Prevalence of self-medication for skin diseases: a systematic review*
}

\author{
Mariane Corrêa-Fissmer ${ }^{1}$ \\ Anesio Henrique Martins ${ }^{1}$
}

\author{
Mariana Gaspar Mendonça ${ }^{1}$ \\ Dayani Galato ${ }^{1}$
}

DOI: http://dx.doi.org/10.1590/abd1806-4841.20142872

\begin{abstract}
Self-medication is the selection and use of drugs without medical prescription, to treat diseases or for symptomatic relief. This article is a systematic review on self-medication in skin diseases. A search was conducted on Virtual Health Library and PubMed databases using predetermined descriptors. Two researchers performed the article selection process independently, with the degree of inter-observer agreement measured by the kappa index. The prevalence of self-medication ranged from 6.0 to $45.0 \%$. Topical corticosteroids were the most commonly used therapeutic strategies for self-medication, as found in the reviewed articles. This study revealed that published data on self-medication in dermatology are scarce, although the findings showed that it was a common practice.
\end{abstract}

Keywords: Dermatology; Self medication; Skin diseases

\section{INTRODUCTION}

The World Health Organization (WHO) defines self-medication as the selection and usage of prescription drugs without medical prescription, in order to treat diseases or promote symptomatic relief. This practice, along with other actions of healthcare such as hygiene practices, nutrition and leisure, are part of self-care. ${ }^{1}$

The selection of drugs in this process should be rational, thus considered when patients use medications which are suitable to their clinical needs, with doses that are adequate to their individual requirements, for an appropriate period of time and with the lowest cost to them and the community. ${ }^{2}$

However, regardless of the use of drugs occurring as self-medication or through prescription, the literature points to a high prevalence of non-rational use, with over $50 \%$ of medications being misused. ${ }^{3}$

Frequent motivators for self-medication are the reuse of previous prescriptions, sharing medications with family and friends due to household stocks, and the advice from sales personnel in retail establishments. ${ }^{4-8}$ Self-medication is also encouraged by drug advertisements and easy access to these products in pharmacies. ${ }^{7.8}$
The prevalence of self-medication is widely variable. In Brazil, the rates among adults vary from $46 \%$ to $53.3 \%$. $^{9}$ A systematic review on self-medication among children and adolescents found prevalence rates ranging from 7.0 to $67.0 \%$, depending on the study characteristics and the pediatric population evaluated. ${ }^{4}$

We highlight some factors as self-medication stimulators, and among them we must cite the media. This is due to the fact that medications are regarded as commodities, with franchised sales for profit. ${ }^{8}$ In this context, a study that analyzed promotional advertising records in pharmacies observed 2,444 publicized products. Of these, $27 \%$ were drugs, of which $3.7 \%$ represented dermatological products. ${ }^{10}$

The dermatological health problems that can motivate self-medication are numerous. According to the census conducted by the Brazilian Society of Dermatology (SBD) in 2006, in public and private dermatological practices, $49 \%$ of patients seeking specialized care were in the age group between 20 and 49 years of age. Among the ten most prevalent dermatoses detected were acne and superficial mycoses, followed in descending order by pigmentation disorders, actinic keratosis, contact dermatitis, seborrheic

Received on 16.06.2013.

Approved by the Advisory Board and accepted for publication on 08.07.2013

Work performed at Universidade do Sul de Santa Catarina (UNISUL) - Tubarão (SC), Brazil.

Conflict of interest: None

Financial Support: None

Universidade do Sul de Santa Catarina (UNISUL) - Tubarão (SC), Brazil.

C2014 by Anais Brasileiros de Dermatologia 
dermatitis, warts, melanocytic nevi, dermatitis such as eczema, dyshidrosis and pityriasis alba and psoriasis. ${ }^{11}$

Patients can perceive some skin problems as irrelevant and self-limited, often engaging in selfmedication before they seek medical care. In these situations the use of topical drugs is frequent, often without apprehensions about adverse events such as bacterial resistance and masking of skin diseases. ${ }^{12}$

Although seen in clinical practice, there are few published studies that describe the process of selfmedication in dermatology. The purpose of this article is to systematically review and describe the prevalence of self-medication in skin diseases, as well as the main pharmacological strategies used.

\section{METHODS \\ QUALIFICATION OF RESEARCHERS AND SELECTION PROCESS}

Two authors individually reviewed the articles for this publication. The articles' selection process was qualified using the kappa index to assess inter-observer agreement. In case of disagreement about the selected articles, other authors were invited to a consensus meeting.

\section{INFORMATION SOURCES AND SEARCH} STRATEGY

The research for inclusion of articles in this review was performed on April 2, 2013. Virtual Health Library (VHL) and PubMed databases were used. The keywords selected were "self medication" AND "dermatology" and "self medication" AND "skin diseases". On VHL database keywords in Portuguese were also investigated: "self-medication" AND "dermatology" and "self-medication" AND "skin diseases". The search was not limited to language of publication, gender and age of the study participants.

\section{SELECTION CRITERIA}

The selection process occurred in four sequential steps. First step: Articles with titles duplicated in the databases were excluded. Second step: All titles were read and those that mentioned self-medication for dermatological conditions, alternative therapies for dermatological conditions, profile of medication use in dermatologic conditions and use of non-prescribed medications and treatments in dermatologic conditions were selected.

Third step: the abstracts of the selected articles were evaluated. Articles with unavailable abstracts on databases, case reports, review articles and abstracts that did not mention the self-medication or its frequency were all excluded.

Fourth step: all selected articles were fully reviewed to assess their connection with the subject. In this step we also performed an analysis of their bib- liographic references to identify new articles of potential interest.

Consensus meetings were held in case of divergence regarding the selected articles

\section{DEPENDENT VARIABLE}

To identify the prevalence of self-medication in dermatology was the main outcome of this review article.

\section{DATA EXTRATION PROCESS IN SELECT- ED ARTICLES}

The following characterization data were extracted from the selected articles: authorship, sample size, study design, main objective, age group, place and year of study, country of origin and data collection environment. The prevalence of self-medication for dermatological conditions described in studies was identified.

Two researchers performed this step independently after reading each article and in case of disagreement a consensus meeting was held.

\section{DATA SYNTHESIS PRESENTATION FORMAT}

Information concerning the characterization of the identified studies and therapeutic strategies adopted as self-medication were presented in a descriptive format.

\section{RESULTS}

Figure 1 shows the selection process of articles included in this review. Also depicted are the reasons for exclusion and inclusion of a new article through reference searches.

Inter-observer agreement (kappa) in the first step of selection was 0.957 ( $p<0.001$ ), in the second step 0.787 ( $p<0.001)$, in the third step that corresponded to abstract analysis it was 0.841 ( $p<0.001)$, with these same articles being select for the fourth step.

The prevalence of self-medication for dermatological conditions ranged from 6.0 to $45.0 \%$ depending on the study, the investigated population and the method applied. Data collection in the studies was obtained from inpatient and outpatient sources.

Methodology characteristics for all included studies are presented in table $1 .^{12-7}$ Table 2 depicts data on study sample and self-medication prevalence for dermatological conditions. ${ }^{12-7}$

Table 3 presents the description of dermatological conditions studied or identified and the drugs used as self-medication in each skin disease. According to the data presented in this table, it is possible to classify the results obtained from the articles into two categories: self-medication in several dermatological conditions (general dermatology) and selfmedication in specific dermatoses (Table 3). ${ }^{12-7}$ 


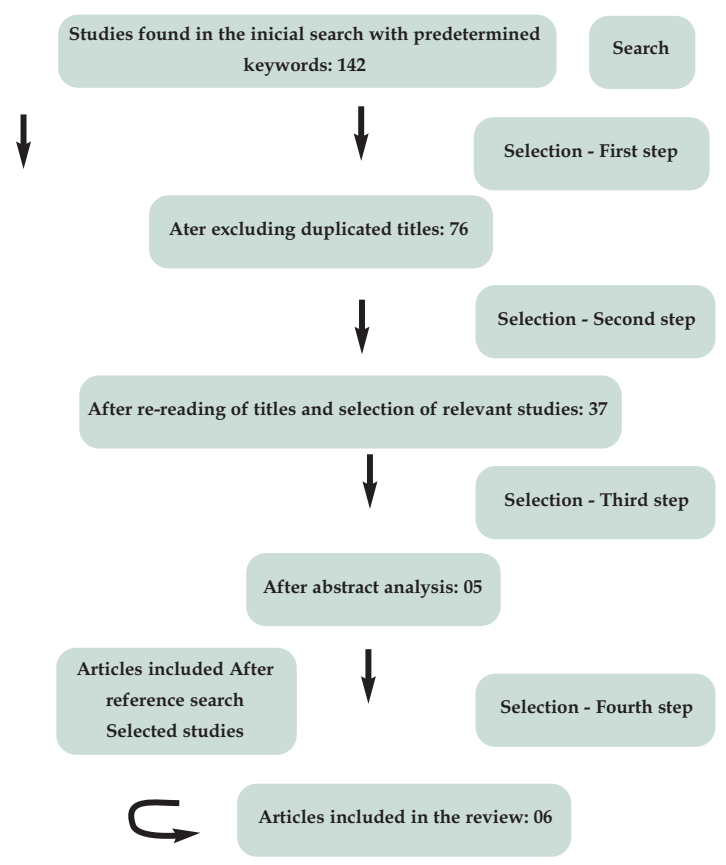

FIGURE 1: Flowchart of the selection process for this review

\section{DISCUSSION}

Although self-medication is an integral part of self-care as proposed by $\mathrm{WHO}$, it is extremely important to evaluate its rationality, because this is a very common practice and the inappropriate use of medications can have serious consequences to the health of individuals as well as the community. ${ }^{1,2}$

These consequences can occur with medications used both topically as systemically, when managing various skin diseases..$^{17,18}$ This becomes especially relevant in children and newborns, since their skin has an immature epidermal barrier, being more susceptible to toxic effects, decreased defense and dryness. ${ }^{19}$ It is noteworthy that self-medication in this population can be considered as that practiced by their parents or caregivers..$^{20}$

The studies identified in this review have widely variable prevalence rates for self-medication in the treatment of various dermatological conditions from 6.0 to $44.0 \%$, with the use of several therapeutic alternatives, especially topical corticosteroids..$^{12-17}$

We noted that there was no uniformity in the presentation of the therapeutic strategies used in selfmedication. WHO recommends the adoption of ATC (Anatomical Therapeutic Chemical) classification for

TABLE 1: Characteristics of included articles according to author, publication year, country, design and objectives

\begin{tabular}{|c|c|c|c|}
\hline Authors & $\begin{array}{l}\text { Publication year/ } \\
\text { Country }\end{array}$ & Study design & Objectives \\
\hline $\begin{array}{l}\text { Padoveze, Ferreira, } \\
\text { Nasimento et } a 1^{12}\end{array}$ & 2012/Brazil & Transversal & $\begin{array}{l}\text { Identify self-medication prevalence for topical } \\
\text { treatment before medical consultation in patients } \\
\text { under } 18 \text { years of age }\end{array}$ \\
\hline $\begin{array}{l}\text { Mouhari-Toure, } \\
\text { Kambaté, Saka et al }{ }^{13}\end{array}$ & 2010/ Togo & Transversal & $\begin{array}{l}\text { Detect self-medication prevalence before } \\
\text { medical consultation }\end{array}$ \\
\hline Kovacs and Brito $^{14}$ & 2006/ Brazil & Transversal & $\begin{array}{l}\text { Check the perception of patients with scabies } \\
\text { regarding the disease, possible diagnoses, type } \\
\text { of drugs used in self-medication and feelings on } \\
\text { the diagnosis }\end{array}$ \\
\hline $\begin{array}{l}\text { Kilkenny, Stathakis, } \\
\text { Jolley et } a l^{15}\end{array}$ & 1998/ Australia & Transversal & $\begin{array}{l}\text { Determine self-recognition prevalence on } \\
\text { dermatoses in the previous two weeks and } \\
\text { previous six months, establish the therapeutic } \\
\text { strategies used and which was the self-medica- } \\
\text { tion practice adopted. }\end{array}$ \\
\hline $\begin{array}{l}\text { Kivelevitch, tahhan, } \\
\text { Bourren } \text { et }^{1 l^{16}}\end{array}$ & 2012/ Argentina & Transversal & $\begin{array}{l}\text { Determine the frequency of self-medication and } \\
\text { non-adherence to treatment amongst patients } \\
\text { with psoriasis }\end{array}$ \\
\hline $\begin{array}{l}\text { Estève, Ah-Toye, } \\
\text { Nseir et al }{ }^{17}\end{array}$ & 2005/ France & Transversal & $\begin{array}{l}\text { Determine the frequency of self-medication in } \\
\text { hospitalized patients }\end{array}$ \\
\hline
\end{tabular}


TABLE 2: Characteristics of included articles according to sample size, age group and frequency of self-medication

\begin{tabular}{|c|c|c|c|}
\hline Authors & Sample size (n) & Age group & $\begin{array}{l}\text { Self-medication } \\
\text { frequency }(\%)\end{array}$ \\
\hline Padoveze, Ferreira, Nasimento et al ${ }^{12}$ & 480 & $0-18$ years & 6.0 \\
\hline Mouhari-Toure, Kambaté, Saka et al ${ }^{13}$ & 600 & $10-99$ years (mean 25 years) & 44.0 \\
\hline Kovacs and Brito ${ }^{14}$ & 65 & Adults over 18 years & 55.4 \\
\hline Kilkenny, Stathakis, Jolley et a ${ }^{15}$ & 416 & Adults & 25.0 \\
\hline Kivelevitch, tahhan, Bourren et al ${ }^{16}$ & 176 & Do not specify age groups (mean 49.4 years) & 33.0 \\
\hline Estève, Ah-Toye, Nseir et al ${ }^{17}$ & 111 & Do not specify age groups & 16.0 \\
\hline
\end{tabular}

TABLE 3: Characteristics of included articles according to dermatological condition and medications used

\begin{tabular}{|c|c|c|}
\hline Authors & Dermatological conditions & Medications used \\
\hline $\begin{array}{l}\text { Padoveze, Ferreira, } \\
\text { Nasimento et al }\end{array}$ & Several dermatological conditions & $\begin{array}{l}\text { Topical: anti-acne medications, combinations, corticosteroids, } \\
\text { antifungals, moisturizing products and barrier creams }\end{array}$ \\
\hline $\begin{array}{l}\text { Mouhari-Toure, } \\
\text { Kambaté, Saka et al }{ }^{13}\end{array}$ & Several dermatological conditions & $\begin{array}{l}\text { Topical and systemic medications and also those bought } \\
\text { from street vendors }\end{array}$ \\
\hline Kovacs and Brito ${ }^{14}$ & Scabies & $\begin{array}{l}\text { Topical: Soaps, herbs, antifungal and antibiotic creams, creams } \\
\text { with corticosteroids or antihistamines, anti-scabies lotion }\end{array}$ \\
\hline $\begin{array}{l}\text { Kilkenny, Stathakis, } \\
\text { Jolley et } a l^{15}\end{array}$ & Several dermatological conditions & Do not specify therapeutic strategies used in self-medication \\
\hline $\begin{array}{l}\text { Kivelevitch, tahhan, } \\
\text { Bourren et al }{ }^{16}\end{array}$ & Psoriasis & Do not specify therapeutic strategies used in self-medication \\
\hline $\begin{array}{l}\text { Estève, Ah-Toye, } \\
\text { Nseir et al }\end{array}$ & Several dermatological conditions & $\begin{array}{l}\text { Topical: Antiseptics, corticosteroids, antibiotics, anti-herpetic, } \\
\text { others. } \\
\text { Systemic: analgesics, anti-histamines, antibiotics and } \\
\text { corticosteroids. }\end{array}$ \\
\hline
\end{tabular}

pharmacoepidemiology studies. ${ }^{21}$ This classification has five levels, from the anatomical region where the drug acts (first level) to the description of the active principle itself (fifth level). Drugs used in the skin are categorized in the first level as " $\mathrm{D}$ ". However, other drugs used systemically in skin diseases such as antibiotics, antihistamines and corticosteroids for oral or parenteral use, belong to other anatomical groups. In this case, studies that adopt ATC to describe a medication do not warrant that the motivation to use that drug can be inferred by the classification, which may justify the lack of its use in dermatological studies.

Exemplifying this limitation of ATC, Oliveira et al, during the determination of use profile of prescribed and non-prescribed medications from birth to two years of age, observed that the age of 3 months corresponded to the phase with the greater use of dermatologic drugs (D01 and D02: antifungals, emollients and protective products). ${ }^{22}$ This finding could be even more impressive in this age group and also at ages 12 and 24 months, if the authors considered, for example, the systemic use of antihistamines and corticosteroids to treat skin problems.

All studies selected for this review had a crosssectional design. This methodology has limitations that are inherent to its design, among which we highlight the recall bias. This is particularly relevant, because in most of the identified studies the recall period used to define the practice of self-medication is not described.

Moreover, the diversity of objectives and populations investigated, either by age or by the country where the study was conducted, would explain the range of prevalence rates found.

Padoveze et al found a lower prevalence of selfmedication, possibly because they considered only topical treatments. ${ }^{12}$ The lack of detailed information on the profile of respondents such as age-related skin problems hinders a better understanding of this finding. Divergences in individual understanding on the practice of self-medication and what the patients consider as topical medications may also explain such result. In this case, for example, the use of barrier creams for the diaper area, by reusing old prescriptions, may have been disregarded by some members of the sample when answering the questionnaire, which could explain this lower prevalence compared to other studies.

The selected studies on self-medication were conducted in different countries. ${ }^{12-17}$ However, we 
identified a larger number of developing countries, which may be justified by the greater relevance of selfmedication in these places, due to fewer financial resources for proper medical care.

A study performed in Togo, Africa, showed the highest prevalence rate of self-medication for dermatological conditions $(44.0 \%)$, with many of the drugs obtained from street vendors..$^{13}$ This fact corroborates the hypothesis of lack of financial resources, that causes patients to seek cheaper alternatives within selfmedication. It is worth noting that a lower economic condition is often associated with low socio-cultural level, which makes it even more difficult to self-recognize symptoms and select a proper therapeutic alternative for self-medication in a rational manner.

This can be illustrated by the study of Kovacs and Brito that evaluated self-medication to treat scabies. ${ }^{14}$ The authors showed that there is a flaw in the self-recognition of signs and symptoms of scabies, as most patients believed that it was another disease other than scabies. In this case, the choice of drug to be used for self-medication can be even more misguided. Patients used sulfur soap, iodine, potassium permanganate, and also herbs, creams with antifungals, antibiotics, corticosteroids and antihistamines, which in addition to not solving the problem, have a high likelihood of causing adverse reactions such as eczematization of lesions, further aggravating the initial symptoms. ${ }^{14}$

Among the therapeutic strategies used in selfmedication in dermatology we highlight anti-acne drugs, combinations and corticosteroids, as well as antiseptics and anti-herpes medications. ${ }^{12,14,17}$ Regarding the use of systemic medications we emphasize analgesics, antihistamines, antibiotics and corticosteroids. ${ }^{17}$ No adverse events were reported following the use of drugs, possibly because of the self-limited characteristic - often associated with recurrence of many skin diseases and consequent use of drugs for a short term. ${ }^{12-19,22}$

However, an Iraqi study that evaluated the excessive use of topical corticosteroids found as main adverse events facial acne, telangiectasias, hypertrichosis, atrophy, striae, hyperpigmentation and hypopigmentation, pyoderma, tinea incognita and infantile gluteal granuloma. ${ }^{22}$ It is worth mentioning that topical corticosteroids can also cause adrenal suppression, and the use of single or combined topical antibiotics may induce the selection of resistant bacteria. ${ }^{12,19}$

Some studies, even though addressing selfmedication, did not describe the products used.

\section{FINAL CONSIDERATIONS}

In performing this review on self-medication applied to dermatology, we sought to identify papers that addressed the problem. The results demonstrate the need for further studies on this topic, with more detailed and elucidative answers that have the statistical validity to support the information found in daily clinical practice. 


\section{REFERENCES}

1. Apps.who.int [Internet]. World Health Organization. The role of the pharmacist in self-care and self-medication. Geneva; 2011 [cited 2011 aug 28]. Available from: http://apps.who.int//medicinedocs/en/d/whozip32e/.

2. Organización Mundial de la Salud (OMS). Uso racional de los medicamentos: informe de la Conferencia de Expertos. In: Conferencia de Expertos sobre uso racional de los medicamentos; 1985 nov 25-29, Nairobi, Kenia. Ginebra: OPAS; 1986.

3. World Health Organization. The world medicines situation. Geneve: World Health Organization; 2011.

4. Pfaffenbach G, Tourinho FSV, Bucaretchi F. Self-medication among children and adolescentes. Curr Drug Saf. 2010; 5:324-28.

5. Beckhauser GC, Souza JM, Valgas C, Piovezan AP, Galato D. Utilização de medicamentos na pediatria: a prática da automedicação em crianças por seus responsáveis. Rev Paul Pediatr. 2010;28:262-8.

6. Carvalho DC, Schuelter-Trevisol F, Menegali B, Trevisol DJ. Uso de medicamentos em crianças de zero a seis anos matriculadas em creches de Tubarão, Santa Catarina. Rev Paul Pediatr. 2008;26:238-44.

7. Ribeiro MA, Heineck, I. Estoque domiciliar de medicamentos na comunidade ibiaense acompanhada pelo programa de saúde da família, em Ibiá-MG, Brasil. Saúde Soc São Paulo. 2010;19:653-63.

8. Vilarino JF, Soares IC, Silveira CM, Rödel APP, Bortoli R, Lemos RR. Perfil da automedicação em município do sul do Brasil. Rev Saúde Pública. 1998;32:43-9.

9. Loyola Al, Filho, Uchoa E, Guerra HL, Firmo JOA, Lima-Costa MF. Prevalência e fatores associados à automedicação: resultados do projeto Bambuí. Rev Saúde Pública. 2002;36:55-62.

10. Galato D, Pereira GB, Valgas C. Análise de informes publicitários distribuídos em farmácias e drogarias. Rev Saúde Pública. 2011;45:212-5.

11. Sbd.org.br [Internet]. Censo Dermatológico da SBD - Sociedade Brasileira de Dermatologia, 2006. [acesso 20 mar 2013]. Disponível em: http://www.sbd.org.br/down/censo_dermatologico2006.pdf

12. Padoveze EH, Nascimento LF, Ferreira FR, Neves VS. Cross-sectional descripte study of topical self-medication in a hospital dermatology department in the state of São Paulo. An Bras Dermatol. 2012;87:163-5.

13. Mouhari-Toure A, Kombaté K, Saka B, Akakpo S, Boukari OB, Pitche P, et al. Selfmedication for dermatologic conditions in Lomé, Togo. Med Trop (Mars). 2010;70:303-4.

14. Kovacs FT, Brito MFM. Disease perception and self medication in patients with scabies. An Bras Dermatol. 2006;81:335-40.

15. Kilkenny M, Stathakis V, Jolley D, Marks R. Maryborough skin health survey: prevalence and sources of advice for skin conditions. Australas $\mathrm{J}$ Dermatol. 1998;39:233-7.

16. Kivelevitch DN, Tahhan PV, Bourren P, Kogan NN, Gusis SE, Rodríguez EA. Selfmedication and adherence to the treatment in psoriasis. Int $\mathrm{J}$ Dermatol. 2012;51:416-9.

17. Estève $E$, Ah-Toye $C$, Nseir $A$, Martin L. Use of non prescription drugs for acute dermatoses.A prospective study of 111 hospitalized patients. Ann Dermatol Venereol. 2005;132:372-3.

18. Al-Dhalimi MA, Aljawahiry N, Misuse of topical corticosteroids: a clinical study in an Iraqi hospital. East Mediterr Health J. 2006;12:847-52.

19. Fernandes JD, Machado MCR,Oliveira ZNP. Children and newborn skin care and prevention. An Bras Dermatol. 2011:86:102-10.

20. Arrais PSD, Coelho HLL, Batista MCDS, Carvalho ML, Righi E, Arnau. Perfil da Automedicação no Brasil. Rev Saúde Pública. 1997;31:71-7.

21. World Health Organization. Anatomical Therapeutic Chemical Classification (ATC). [cited 2011 May 3] Disponível em: http://www.who.int/classifications/atcddd/en/

22. Oliveira EA, Bertoldi AD, Domingues MR, Santos IS, Barros ADJ. Uso de medicamentos do nascimento aos dois anos: Coorte de nascimento de pelotas, RS, 2004. Rev Saúde Pública. 2010;44:591-600.

\author{
MAILING ADDRESS: \\ Mariane Corrêa-Fissmer \\ Av. José Acácio Moreira, 787 - Dehon \\ 88704-900 - Tubarão - SC \\ Brazil \\ E-mail:marianecfissmer@gmail.com
}

How to cite this article: Corrêa-Fissmer M, Mendonça MG, Martins AH, Galato D. Prevalence of self-medication for skin diseases: a systematic review. An Bras Dermatol. 2014;89(4):625-30. 